\title{
The influence of halloysite on the physicochemical, mechanical and biological properties of polyurethane- -based nanocomposites
}

\author{
Maciej Mrówka1), *), Małgorzata Szymiczek ${ }^{1)}$, Tomasz Machoczek ${ }^{1)}$, Joanna Lenża ${ }^{2)}$, Jakub Matusik ${ }^{3)}$, \\ Piotr Sakiewicz ${ }^{4)}$, Magdalena Skonieczna ${ }^{5), 6)}$
}

DOI: dx.doi.org/10.14314/polimery.2020.11.5

\begin{abstract}
The impact of the addition of the nanofiller - halloysite - on the mechanical, physicochemical and biological properties of a nanocomposite, in which thermoplastic polyurethane fulfilled the role of the matrix was investigated. The nanocomposite was obtained by extrusion in three variants with 1,2 and $3 \mathrm{wt} \%$ halloysite. The nanostructure of the obtained materials was confirmed using Atomic Force Microscopy (AFM). Based on the mechanical tests carried out, it was proven that the obtained nanocomposites were characterized by a tensile modulus greater than the polyurethane constituting the matrix. The density and hardness of the nanocomposites had changed within error limits compared to unmodified polyurethane. Biological tests showed no cytotoxicity of all the tested materials to normal human dermal fibroblasts (NHDF). Degradation tests were carried out in artificial plasma and showed that samples with $2 \mathrm{wt} \%$ halloysite addition had the best ratio of tensile strength and elongation at break to elasticity modulus.
\end{abstract}

Keywords: nanocomposites, thermoplastic polyurethanes, halloysite, mechanical properties, cytotoxicity tests, degradation.

\section{Wpływ dodatku haloizytu na fizykochemiczne, mechaniczne i biologiczne właściwości nanokompozytów na osnowie termoplastycznego poliuretanu}

Streszczenie: Zbadano wpływ naturalnego nanonapełniacza - haloizytu - na właściwości mechaniczne, fizykochemiczne oraz biologiczne kompozytu wytworzonego na bazie termoplastycznego poliuretanu. Nanokompozyt o zawartości 1, 2 i 3\% mas. haloizytu otrzymywano na drodze wytłaczania. Nanostrukturę wytworzonych materiałów potwierdzono za pomocą mikroskopii sił atomowych (AFM). Na podstawie przeprowadzonych badań mechanicznych wykazano, że uzyskane nanokompozyty charakteryzują się modułem sprężystości większym niż poliuretan stanowiący osnowę. Zmiany gęstości i twardości niemodyfikowanego poliuretanu po dodaniu haloizytu mieściły się w granicach błędu pomiaru. Testy biologiczne nie wykazały cytotoksyczności wszystkich badanych materiałów wobec prawidłowych fibroblastów ludzkiej skóry (NHDF). Badania degradacji przeprowadzone w środowisku syntetycznego osocza wykazały, że próbki z dodatkiem $2 \%$ mas. haloizytu mają najlepszy stosunek wytrzymałości na rozciąganie i wydłużenia przy zerwaniu do modułu sprężystości.

Słowa kluczowe: nanokompozyty, termoplastyczne poliuretany, haloizyt, właściwości mechaniczne, badania cytotoksyczne, degradacja.

\footnotetext{
1) Silesian University of Technology, Faculty of Mechanical Engineering, Department of Theoretical and Applied Mechanics, Konarskiego 18A, 44-100 Gliwice, Poland.

2) Krahn Chemie Polska Sp. z o.o., Marcelińska 90, 60-324 Poznań, Poland.

3) AGH University of Science and Technology, Faculty of Geology, Geophysics and Environmental Protection, Department of Mineralogy, Petrography and Geochemistry, Mickiewicza 30, 30-059 Krakow, Poland.

4) Silesian University of Technology, Faculty of Mechanical Engineering, Department of Engineering Materials and Biomaterials, Konarskiego 18A, 44-100 Gliwice, Poland.

5) Silesian University of Technology, Biotechnology Centre, Krzywoustego 8, 44-100 Gliwice, Poland.

6) Silesian University of Technology, Department of Systems Biology and Engineering, Akademicka 16, 44-100 Gliwice, Poland.

*) Author for correspondence: maciej.mrowka@polsl.pl
} 
Due to the appropriate properties (i.e. flexibility to a wide range of hardness levels, resistance to abrasion and cracking) linear thermoplastic polyurethanes (LTPURs) are used in the production of tissue and alloprosthetics for filling tissue lesions [1-4]. This material is characterized by: high tensile and breaking strength, a wide range of hardness levels, a high value of the maximal strain, high elasticity, resistance to fatigue, low deformation at static and dynamic loads, low abrasibility and low moisture absorption [1,5-8]. LTPURs serve for the production of elements of artificial cardiac valves, artificial blood vessels, elements of artificialoesophaguses and breast implants [5-7,9]. The increasing length of human life and the necessity to restore the health of accident or disease victims results in a need for researchers to develop new materials that exhibit improved mechanical properties compared to traditionally applied materials [10-12].

One solution that would improve the properties of LTPURs is the introduction of nanofillers into the polymer matrix [13]. Selection of the appropriate filler may allow the simultaneous introduction of particular drugs into the human organism. Due to its microstructure, halloysite may be a sufficient nanofiller [14]. This aluminosilicate mineral exhibits a $1: 1$ layered structure and is characterized by a tubular-plate or tubular morphology [13-15]. Most often, smectite and kaolin groups are applied in the synthesis of nanocomposites. Halloysite is one of the clay minerals classified within the kaoliniteserpentinite group. It often forms very fine crystals in the deposits, exhibiting tubular-plate like structures [14].

Research has proven that halloysite does not exhibit toxicity to humans, which - combined with its tubular structure - allows the design of a controlled release system for medicines based on halloysite-medicine intercalation compounds [13-15]. The use of biocompatible halloysite as a filler in the production of nanocomposites in which LTPURs serve as a matrix allowed for improvement in the mechanical properties of new materials [14-16]. Uniform distribution of halloysite grains in the composite material is, however, hard to achieve due to hydrophilic character of the mineral. The polyurethanes used in this study are hydrophobic, while halloysite is hydrophilic due to the presence of surface $\mathrm{OH}$ hydroxyls, as well as water molecules within the clay particles. Uniform distribution may be achieved by organic modification of the filler, maximizing the chemical compatibility of the filler to the polymer constituting the matrix $[14,15]$. Surfactants are most often used for such modifications, allowing for the nanofiller to act in synergy with the polymer [16]. Research has exhibited that an addition of as little as $1 \mathrm{wt} \%$ halloysite to LTPUR achieved a 3-fold increase in the tensile modulus, as compared to the polyurethane used as a matrix [17]. Other studies have shown that an addition of $1 \mathrm{wt} \%$ halloysite causes an increase in tensile strength by $3.59 \mathrm{MPa}$, as compared to the polyurethane constituting the matrix [18]. Yet another study exhibited an increase in the tensile strength by $26 \%$ and an increase of the tensile modulus by $83 \%$ with 2 wt \% halloysite in the polyurethane nanocomposite [19]. There was also a study in which the tensile modulus increased by $40 \%$ with a halloysite content of $3.7 \mathrm{wt} \%$ [20]. The presented research describes methods for the production of polyurethane-based nanocomposites with the use of halloysite.

Relatively few papers include cytotoxicity tests of this type of material. In addition, modification of LTPUR properties with nanoparticles requires aging tests in a biologically active environment.

The aim of this work was to determine the effect of halloysite addition on the mechanical, physicochemical and biological properties of nanocomposites based on LTPUR. Considering the potential application of nanocomposites in medicine, degradation research was conducted in an artificial plasma environment.

\section{EXPERIMENTAL PART}

\section{Materials}

The research was carried out on nanocomposites based on LTPUR filled with halloysite. Halloysite was obtained from Dunino deposit, located near Legnica (SW Poland), which is owned by Intermark Company [22]. Halloysite from Dunino deposit contains both platy and tubular particles (Fig. 1).

The mineral composition is as follows: $75-80 \%$ halloysite, $18-22 \%$ iron oxides (mainly hematite and magnetite) and $2-4 \%$ titanium oxides (mainly ilmenite). The compounds of iron and titanium in the sample are in the form of loosely embedded grains up to $0.4 \mathrm{~mm}$ in size. About $30 \%$ of the structure of this mineral is rigid, simple nanotubes [called halloysite nanotubes (HNT)] with a diameter of 10-150 $\mathrm{nm}$ and a length of about $2 \mu \mathrm{m}$ $[22,23]$. Before the extrusion process, halloysite was subjected to a process of reducing its hydrophilicity. From the available methods, the method proposed by prof. Jakub Matusiak gave the best results for increasing the

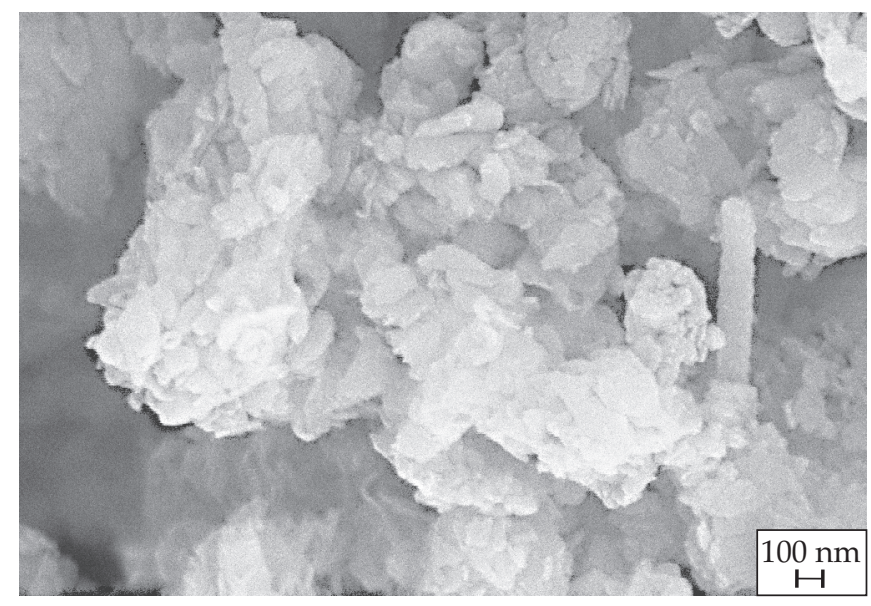

Fig. 1. Microscopic image of halloysite 
hydrophobicity of halloysite. Firstly, the cation exchange capacity (CEC) of the mineral material was determined by using the cobalt(III) hexamine method [24-28]. The measured CEC was equal to $8.02 \mathrm{meq} / 100 \mathrm{~g}$. Secondly the material was modified with hexadecyltrimethylammonium bromide (HDTMA-Br) in an amount equal to $1 \mathrm{CEC}$. For that, an aqueous suspension of halloysite was prepared and HDTMA-Br was introduced in the form of an aqueous solution after sonification. The formed suspension was stirred for $24 \mathrm{~h}$, followed by centrifugation and drying at $70^{\circ} \mathrm{C}$ for $24 \mathrm{~h}$.

Elastollan $1185 \mathrm{~A}$, a polyether based TPUR (thermoplastic polyurethane) purchased from BASF, was used [29].

\section{Preparing of samples}

Tested materials were nanocomposites based on thermoplastic polyurethane filled with modified halloysite at a mass fraction of 1, 2 and 3\%, which gave the following materials: $[\mathrm{E}+1],[\mathrm{E}+2]$ and $[\mathrm{E}+3]$. The nanocomposites were prepared on a Leistritz ZSE 27 HP twin-screw extruder. The nanocomposite extrusion parameters were as follows: zone temperatures $100-190^{\circ} \mathrm{C}$, mass temperature $194^{\circ} \mathrm{C}$, pressure $2 \mathrm{MPa}$, screw rotation $450 \mathrm{rpm}$, and efficiency $20 \mathrm{~kg} / \mathrm{h}$. Samples for all tests were prepared by injection molding on an Arburg Allrounder 270-210500 machine. The temperature was $180-195^{\circ} \mathrm{C}$ and the pressure was $90 \mathrm{MPa}$. Before the extrusion and injection molding process, materials were dried in a convection oven for $3 \mathrm{~h}$ at $110^{\circ} \mathrm{C}$.

\section{Methods of testing}

\section{Atomic force microscopy}

The obtained samples had the shape of a cuboid with dimensions of $10 \times 4 \times 80\left(\mathrm{~mm}^{3}\right)$. Samples were cut from cuboids on a microtome used in tissue engineering and used for the tests. The thickness of the samples was $500 \mu \mathrm{m}$. Atomic Force Microscopy (AFM) in contact mode was used to characterize the surface topography and to confirm the particle size of halloysite in the nanocomposite samples. The measurements were done with a XE-100 microscope from ParkSystems. Data were collected in air at room temperature.

\section{Density test}

Density testing was carried out on an analytical balance OHAUS PR224 equipped with an Archimedes density measurement set according to International standard EN ISO 1183-1:2006 . Measurements were carried out on five samples from each nanocomposite and compared to native samples. Density was determined based on the formula:

$$
d=d_{w} \frac{m_{1}}{m_{1}-m_{2}}
$$

where: $d_{w}$ - pure water density $\left(\mathrm{g} / \mathrm{cm}^{3}\right), m_{1}$ - mass of sample in water $(\mathrm{g}), m_{2}-$ dry sample's mass $(\mathrm{g})$.

\section{Mechanical properties tests}

Tensile strength testing was carried out in accordance with International standard EN ISO 527-1 on a ZWICK Z020 tensile machine equipped with an extensometer. The test speed was $50 \mathrm{~mm} / \mathrm{min}$. The number of samples tested in the population was 5 . The figures show the arithmetic mean value for 5 samples together with the standard deviation value. On the basis of the results obtained during the tensile test, stress and elongation at break and the tensile modulus were determined for each of the tested sample populations.

\section{Shore A hardness test}

The hardness measurements of the tested materials were carried out using the Shore A method. The Shore A hardness test was carried out in accordance with International standard ISO 686. Five measurements were taken on each of the composites made, keeping a distance of at least $10 \mathrm{~mm}$ from edge of the sample and between the individual measurements.

\section{Cytotoxicity test}

The viability of the cells was assessed with 3-[4,5-dimethylthiazol-2-yl]-2,5-diphenyltetrazolium bromide (MTT) test [30]. Normal human dermal fibroblast (NHDF) cells were purchased from Lonza (NHDFNeo, Lonza, Poland). The test materials E, E+1, E+2 and $\mathrm{E}+3$ were placed on Petri plates, and then $10^{5}$ cells were seeded on each plate. The cells were seeded onto the tested materials and incubated for $72 \mathrm{~h}$ at $37^{\circ} \mathrm{C}$ in a humidified atmosphere of $5 \% \mathrm{CO}_{2}$. The culture medium was then removed and replaced with trypsin solution for cell collection. After trypsin neutralization, the cell suspensions were centrifuged (2000 rpm, $3 \mathrm{~min}$, room temperature) and the cell pellet was resuspended in MTT solution $\left(0.05 \mathrm{~cm}^{3}, 0.5 \mathrm{mg} / \mathrm{cm}^{3}\right.$ in RPMI 1640 without phenol red, Sigma). After $3 \mathrm{~h}$ of incubation, the MTT solution was removed and the acquired formazan was dissolved in isopropanol : $\mathrm{HCl}$. Finally, the absorbance at wavelength $570 \mathrm{~nm}$ was measured spectrophotometrically with a plate reader. Three independent repetitions were conducted. The color intensity of the solution is directly proportional to the amount of product and indirectly proportional to the number of dead cells and results were presented as Survival Fraction (\%) in comparison to the untreated control NHDF cells:

$$
\text { viability }=\frac{A_{\text {sample }}}{A_{\text {control }}} \cdot 100 \%
$$

where: $A_{\text {sample }}$ - absorbance of the tested sample, $A_{\text {control }}$ - mean absorbance of the control. 


\section{Degradation tests}

Degradation tests were conducted in accordance with the International standard PN-EN ISO 10993-13:1998 in artificial plasma prepared according to the parameters specified by standard PN-EN ISO 10993-15:2000. The chemical composition of artificial plasma is given in Table 1. All chemical reagents of adequate purity were dissolved in water of purity grade 2 according to ISO 3696. Degradation tests were carried out in accelerated conditions $(2,7,30$ and 60 day) at a temperature of $70 \pm 1^{\circ} \mathrm{C}$. Samples were placed in a glass vessel in artificial plasma. Temperature stability was achieved thanks to the use of a forced dryer.

T a b l e 1. Chemical composition of artificial plasma

\begin{tabular}{c|c}
\hline Chemical reagent & Content $\mathrm{g} / \mathrm{dm}^{3}$ \\
\hline $\mathrm{NaCl}$ & 6.800 \\
$\mathrm{CaCl}$ & 0.200 \\
$\mathrm{KCl}$ & 0.400 \\
$\mathrm{MgSO}_{4}$ & 0.100 \\
$\mathrm{NaHCO}_{3}$ & 2.200 \\
$\mathrm{Na}_{2} \mathrm{HPO}_{4}$ & 0.126 \\
$\mathrm{NaH}_{2} \mathrm{PO}_{4}$ & 0.026 \\
\hline
\end{tabular}

\section{RESULTS AND DISCUSSION}

\section{Atomic force microscopy (AFM)}

The results of microscopic examinations are presented in Fig. 2. Images of structures with different contents are shown in Figs. 2a (E+1), 2b (E+2), 2c (E+3). Figs. 2d (E+1), 2e $(E+2)$ and $2 f(E+3)$ show the nanofiller distribution in the composites.

The average particle size was $57.2 \mathrm{~nm}$ for $\mathrm{E}+1$ (range of particles 36.0-78.4 nm), $43.5 \mathrm{~nm}$ for E+2 (range of particles $23.9-63.1 \mathrm{~nm}$ ) and $73.3 \mathrm{~nm}$ for $\mathrm{E}+3$ (range of particles $59.9-86.7 \mathrm{~nm}$ ). Since the average size of nanoparticles did not exceed $100 \mathrm{~nm}$, it should be stated that in all cases we deal with a nanocomposite.

\section{Results of mechanical tests}

The results of strength tests for both LTPUR and its nanocomposites are presented in Figs. 3-5 (Fig. 3 tensile modulus; Fig. 4 stress at break; Fig. 5 elongation at break).

The tensile modulus increased for all nanocomposites when compared to the samples from native TPUR: E - $26.04 \pm 0.22 \mathrm{MPa}, \mathrm{E}+1-26.35 \pm 1.67 \mathrm{MPa}$, $\mathrm{E}+2-28.4 \pm 1.21 \mathrm{MPa}$ and $\mathrm{E}+3-27.61 \pm 0.33 \mathrm{MPa}$. Gaaz et al. [18] noted a $32 \%$ increase in tensile modulus for nanocomposites with 1 wt \% HNT mass content, while Martini et al. [20] noted a $40 \%$ increase in tensile modulus for nanocomposites with $3.7 \mathrm{wt} \%$ HNT content. The highest grain was observed for a $2 \mathrm{wt} \%$ share of halloysite. For a 3 wt \% filler, the modulus value decreases slightly. It can be stated that for the proposed chemical modification of halloysite and the plate-tube structure of the mineral from the Dunino mine, the best modulus is seen in nanocomposites with a 2 wt \% share of halloysite.

The results of the stress at break testing are presented in Fig. 4. The stress at break values for individual materials are: $\mathrm{E}-28.31 \pm 0.19 \mathrm{MPa}, \mathrm{E}+1-34.01 \pm 0.77 \mathrm{MPa}$, $\mathrm{E}+2-33.1 \pm 0.92 \mathrm{MPa}$ and $\mathrm{E}+3-28.65 \pm 1.09 \mathrm{MPa}$. Gaaz et al. [18] describe a $44 \%$ increase in stress at break for a nanocomposite with $1 \mathrm{wt} \%$ HNT content. In turn, Gaaz et al. [19] showed that a $2 \mathrm{wt} \%$ addition of HNT to the matrix

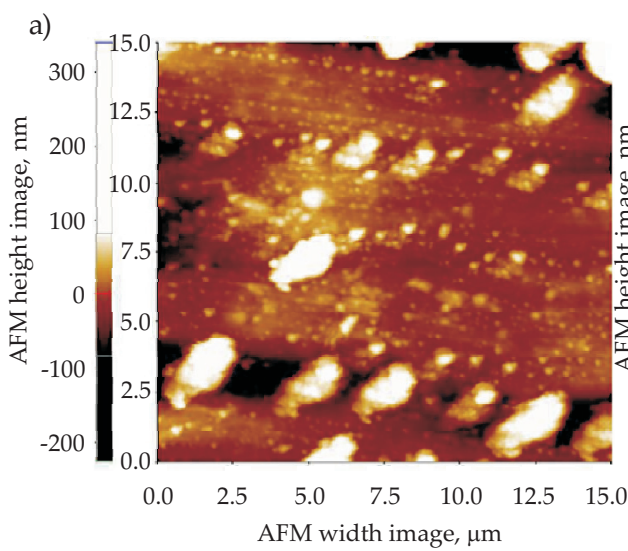

d)

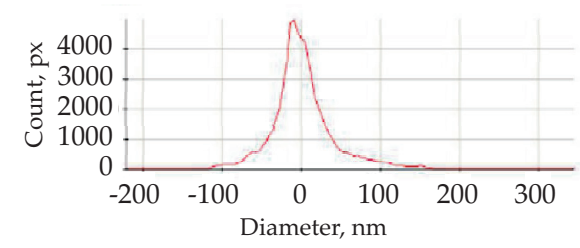

b)

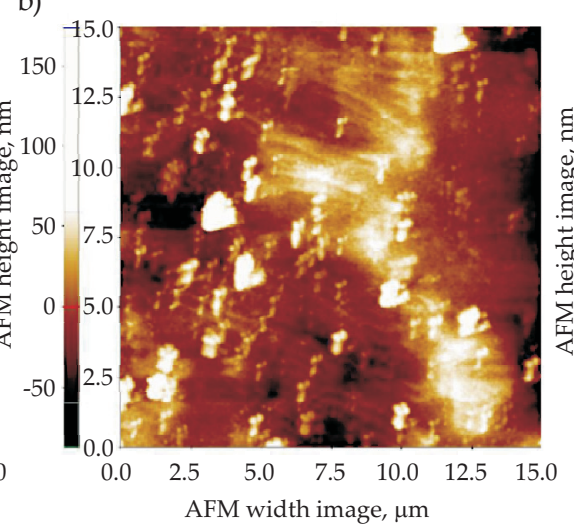

e)

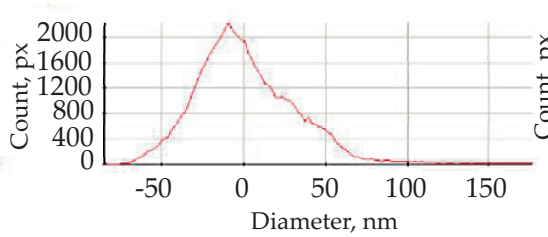

f)

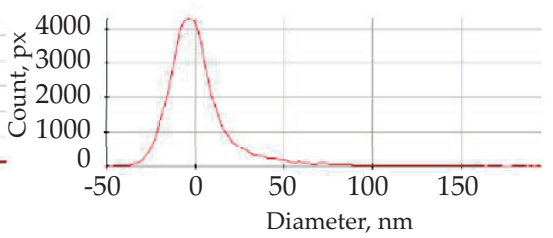

Fig. 2. Structure of the nanocomposites: a) $E+1$, b) $E+2$, c) $E+3$ and their histograms by: d) E+1, e) E+2, f) E+3 atomic force microscope XE-100 


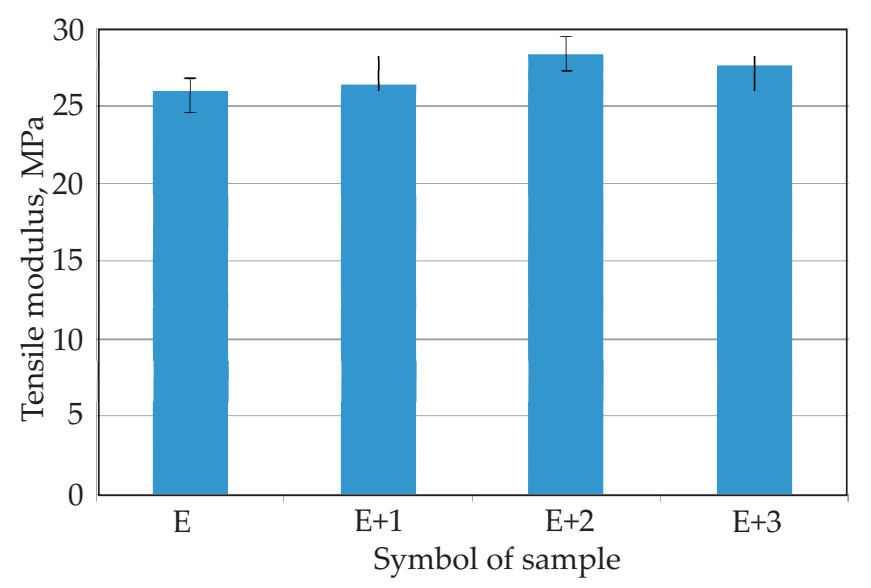

Fig. 3. Results of tensile modulus testing of the prepared composites

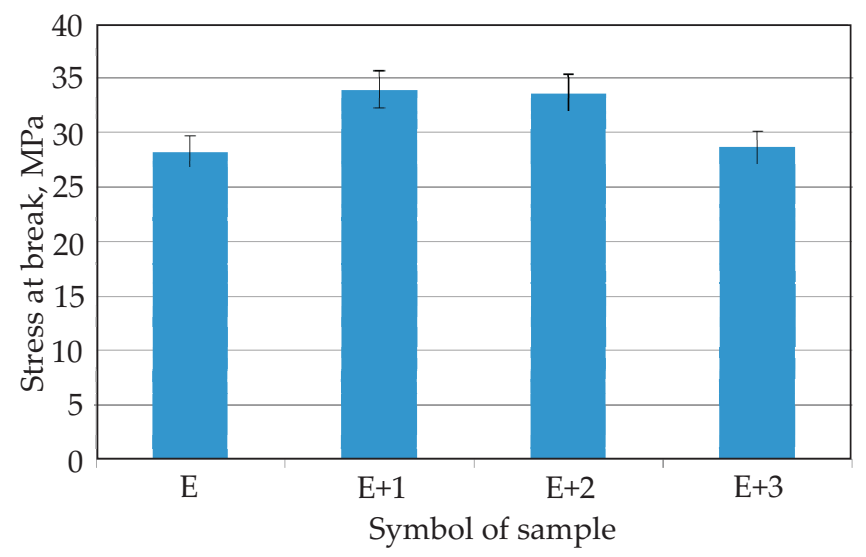

Fig. 4. Results of stress at break testing of the prepared composites

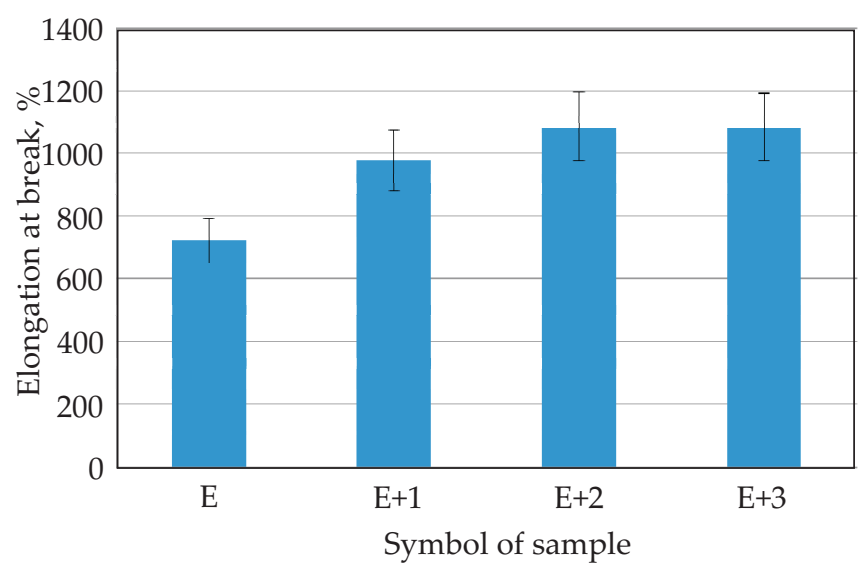

Fig. 5. Results of elongation at break testing of the prepared composites

increased the stress at break by $26 \%$. For nanocomposites with 1 and 2 wt \% halloysite content, an increase in stress at break was observed, which shows that the filler was built into the matrix without forming agglomerates. In the case of $3 \mathrm{wt} \%$ filler content, the stress value decreases slightly and reached approximately the value determined for unmodified polyurethane.

The results of elongation at break testing are shown in Fig. 5. Elongation at break for unmodified TPUR was
$723 \%$, and for $\mathrm{E}+1, \mathrm{E}+2$ and $\mathrm{E}+3$ nanocomposites was 979 , 1084 and 1086\%, respectively. The highest value of elongation at break was assumed for the $\mathrm{E}+3$ nanocomposite. In publications referring to nanocomposites with $2 \mathrm{wt} \%$ HNT content, 67\% [18] and 100\% [19] increased elongation at break have been reported, compared to TPUR acting as the matrix. The obtained results are different from those published in other papers [17-19]. The tests showed an increase in the tensile modulus, but it was lower than had previously been described. For the nanocomposites, there was also a slight decrease in stress at break compared to the unmodified polyurethane. The authors suspect these differences may be due to the use of natural Dunino halloysite. Its structure is characterized by about 30\% nanotube content. The authors of other papers used halloysite nanoclay with $99.5 \%$ nanotube purity purchased from Sigma Aldrich in their studies [17-19].

\section{Results of Shore A hardness test}

Graphical presentations of average hardness values and their standard deviations are presented in Fig. 6. For each variant of the composite, the study was carried out on five samples.

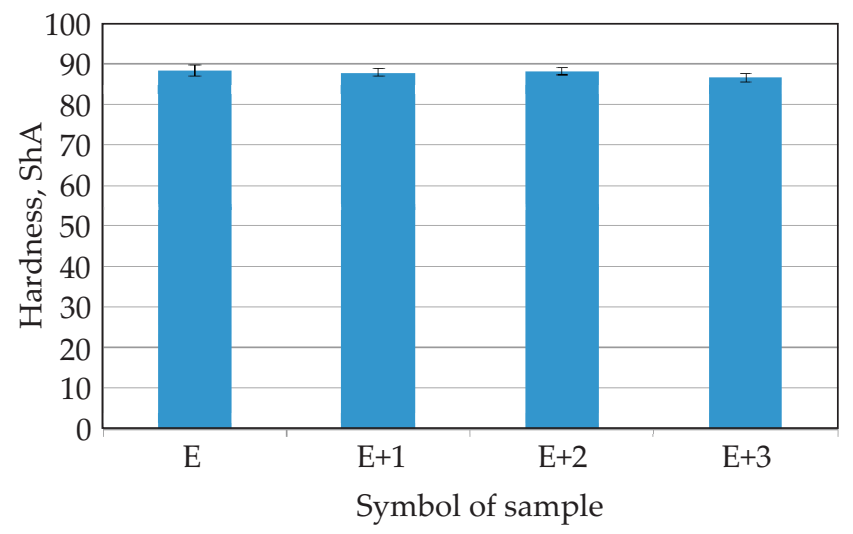

Fig. 6. Results of hardness of the prepared composites

Average hardness values suggest that the addition of halloysite does not affect the hardness of the composites. For unmodified TPUR, the hardness was $88.4^{\circ} \mathrm{Sh} A$, while the hardness of composites $\mathrm{E}+1, \mathrm{E}+2$ and $\mathrm{E}+3$ was $88,88.2$ and $86.8^{\circ} \mathrm{ShA}$, respectively. The lower hardness value for $\mathrm{E}+3$ may be due to the chemical modification of halloysite.

\section{Results of density test}

The density of unmodified TPUR and nanocomposites was determined by measuring five samples. The average values and their standard deviations are shown in Fig. 7.

The unmodified TPUR samples showed a density of $1.12 \mathrm{~g} / \mathrm{cm}^{3}$. The same density was found for the nanocomposites with the addition of halloysite: $\mathrm{E}+1-1.12 \mathrm{~g} / \mathrm{cm}^{3}$, $\mathrm{E}+2-1.12 \mathrm{~g} / \mathrm{cm}^{3}$ and $\mathrm{E}+3-1.12 \mathrm{~g} / \mathrm{cm}^{3}$. The observed changes are within the error limits. The results prove that 


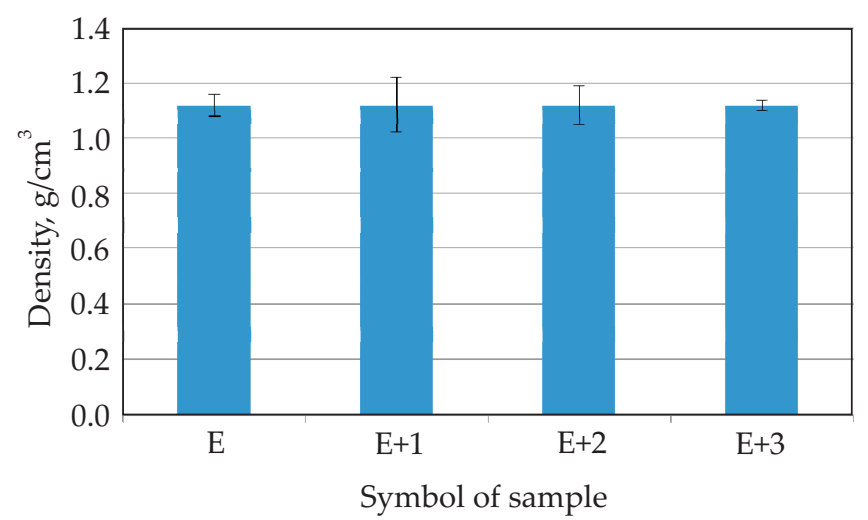

Fig. 7. Density values of the tested composites

the addition of halloysite in an amount of 1-3 wt \% does not significantly affect the density of the nanocomposite, regardless of its mass fraction.

\section{Results of cytotoxicity test}

The results of cytotoxicity tests are presented in Fig. 8 . The results indicate that the unmodified TPUR exhibits little toxicity relative to the control (viability $=96 \%$ ). $\mathrm{E}+1$ and $\mathrm{E}+2$ nanocomposites stimulated proliferation to a small extent, resulting in viability values of 103 and $107 \%$, respectively. E+3 also stimulated the proliferation of the NHDF cell line. The incubation time of the cells with the materials was $72 \mathrm{~h}$ and during this time a certain balance was established in the cell-material system. It should be assumed that in the case of prolonging the culture, the number of cells in the systems where TPUR, E+1 and E+2 were introduced would increase. In the case of E+3, stimulation of $22 \%$ cell proliferation with respect to control was observed. This is probably due to halloysite, which can stimulate the proliferation of the NHDF cell elasticity line. The iron compounds contained in the halloysite (18-22\%) support cell proliferation. Research performed in 2006 [31]

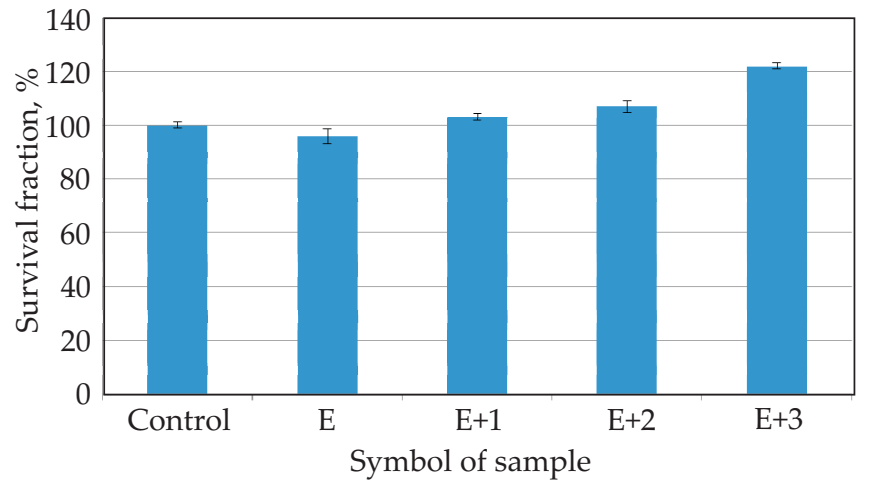

Fig. 8. Cytotoxicity of tested materials against a normal human dermal fibroblast (NHDF) cell line, followed by $72 \mathrm{~h}$ of incubation in a MTT assay

showed an increase in HeparRG ${ }^{\mathrm{TM}}$ (human hepatic cell line) proliferation in response to halloysite.

\section{Results of degradation tests}

The results of changes in mechanical properties depending on the degradation time are shown in Fig. 9 (tensile modulus), Fig. 10 (stress at break) and Fig. 11 (elongation at break).

As can be seen in Fig. 9 the elasticity modulus increases with the content of halloysite and aging time. Stress and elongation at break decreases with content of halloysite and the degradation time. The results were approximated with a second degree polynomial with correlation coefficients above $95 \%$. Approximation functions are shown in Figs. 9-11. Forecasting carried out up to one period confirms the observed changes. It can therefore be concluded that the introduction of the nanofiller above $2 \mathrm{wt} \%$ is not necessary because a significant decrease in stress and elongation at break is observed, which is not proportional to the increase in the modulus of elasticity. The observed dispersion of the studied characteristics increases with the content of halloysite and progressing degradation.

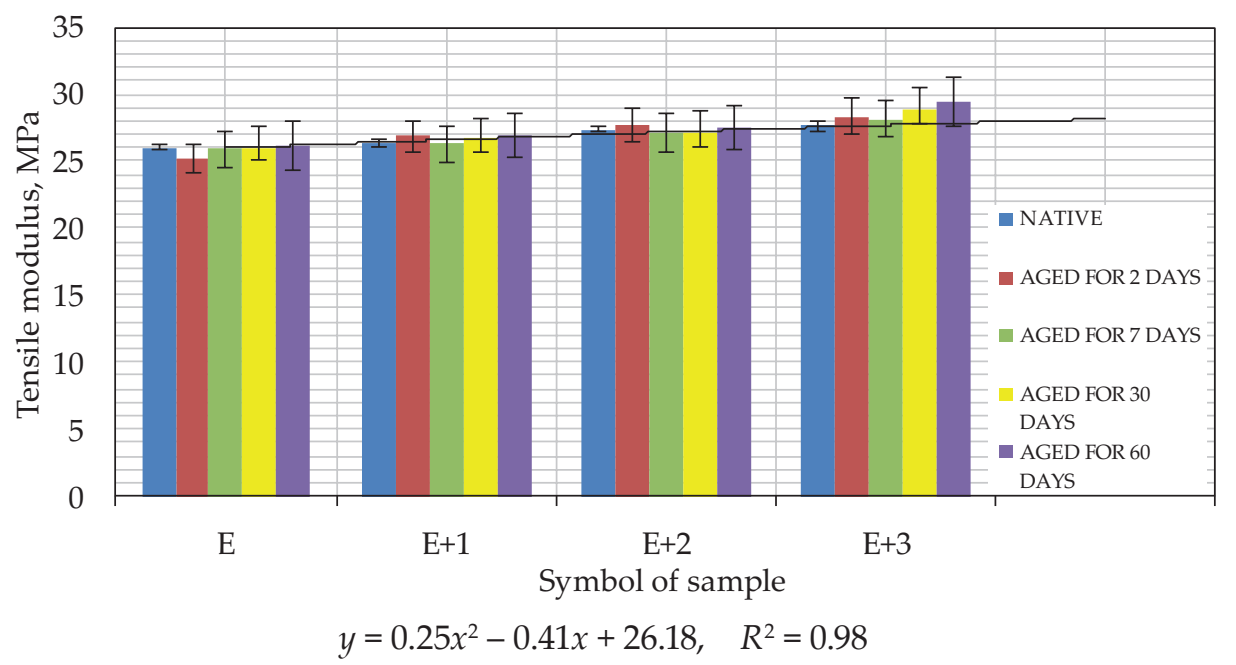

Fig. 9. Tensile modulus of the prepared composites as a function of degradation time 


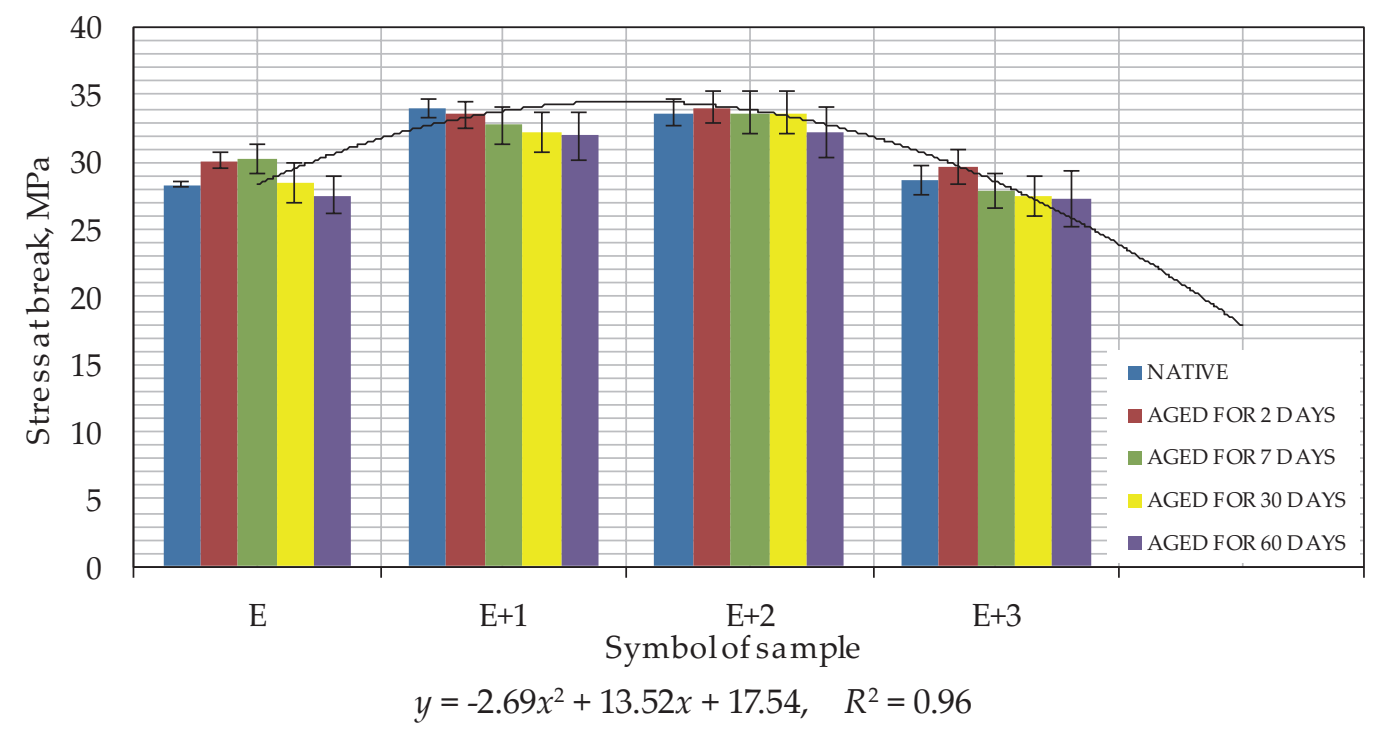

Fig. 10. Stress at break of the prepared composites as a function of degradation time

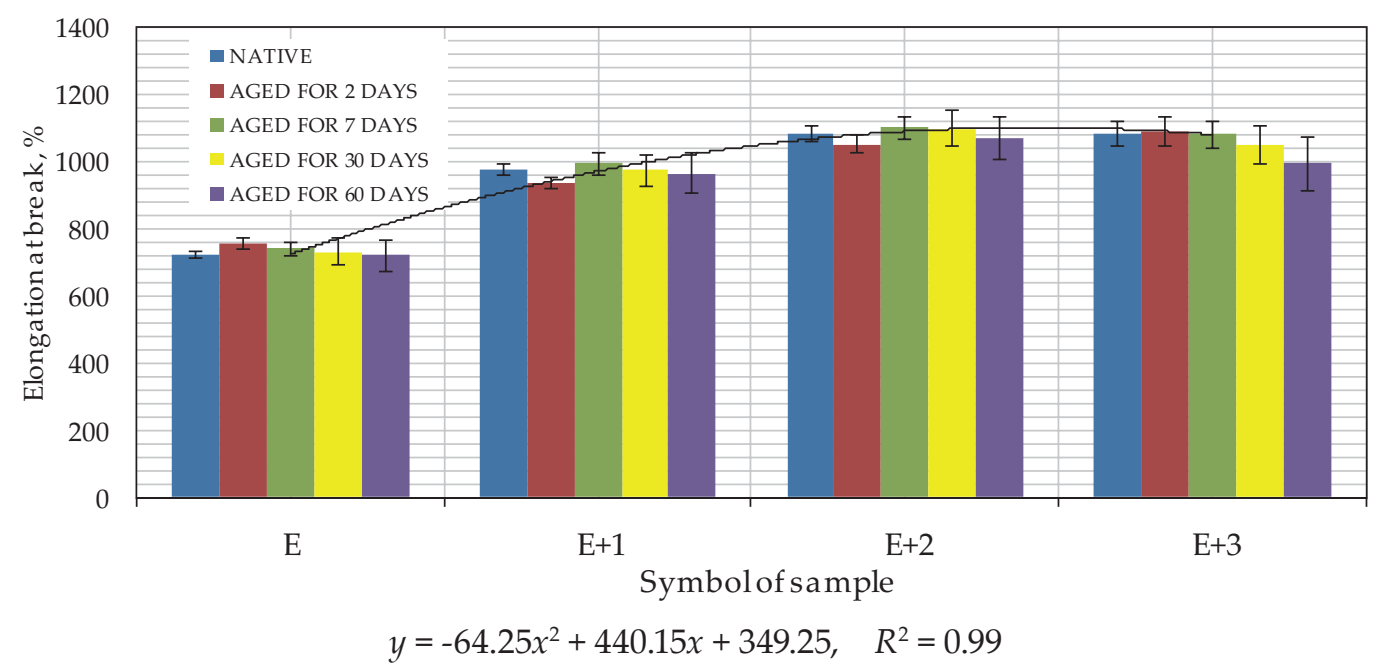

Fig. 11. Elongation at break of the prepared composites as a function of degradation time

\section{CONCLUSIONS}

Based on the results, it can be concluded that:

- The method of obtaining nanomaterials described allows for the obtainment of nanocomposites. All average particle sizes are below $100 \mathrm{~nm}$.

- Introduction of the nanofiller does not cause density changes. Shore A hardness and densities change within error limits for reference samples.

- All samples, regardless of the percentage of the nanofiller, showed a higher tensile modulus than the reference sample. However, the highest tensile modulus was recorded for samples with 2 wt \% filling. The tensile strength for the test samples decreased with increasing filler content. The biggest change was recorded for samples with $1 \mathrm{wt} \%$ filling. The highest elongation was noted for samples with $1 \mathrm{wt} \%$ filling.

- The results of cytotoxicity tests do not indicate a toxic effect of nanocomposites on NHDF cells. The nanocom- posite with the highest content of halloysite ( $3 \mathrm{wt} \%$ ) even stimulates the normal cells' proliferation.

- The results of changes in mechanical characteristics during degradation show that the smallest changes were noted for samples with $2 \mathrm{wt} \%$ nanofilling content. Increasing the content of halloysite causes an increase in the modulus of elasticity but also a significant decrease in stress and elongation at break. However, it should be noted that an important factor influencing the observed changes is the sample preparation technology.

This research did not receive any specific grant from funding agencies in the public, commercial, or not-for-profit sectors.

\section{REFERENCES}

[1] Mrówka M., Szymiczek M., Lenża J.: Journal of Achievements in Materials and Manufacturing Engineering 2019, 95, 13. 
http://dx.doi.org/10.5604/01.3001.0013.7620

[2] Larson E.: "Thermoplastic Material Selection 1st Edition A Practical Guide", Elsevier BV, Amsterdam 2015.

[3] Brzeska J., Dacko P., Janeczek H. et al.: Polimery 2010, $55,41$. http://dx.doi.org/10.14314/polimery.2010.041

[4] Cheremisinoff N.P.: "Materials Selection Deskbook 1st Edition", Elsevier BV, Amsterdam 1996.

[5] Turi E.: "Thermal Characterization of Polymeric Materials", Elsevier BV, Amsterdam 1981.

[6] Olędzka E., Sobczak M., Kołodziejski W.L.: Polimery 2007, 52, 795. http://dx.doi.org/10.14314/polimery.2007.795

[7] Krzyżak A., Kosicka E., Szczepaniak R., Szczepaniak T.: Journal of Achievements in Materials and Manufacturing Engineering 2019, 95, 5. http://dx.doi.org/10.5604/01.3001.0013.7619

[8] Brydson J.A.: "Plastics Materials 5th Edition", Elsevier, eBook ISBN: 9781483144795.

[9] Spirkova M., Pavlicevic J., Strachota A. et al.: European Polymer Journal 2011, 47, 959. https://doi.org/10.1016/j.eurpolymj.2011.01.001

[10] Cooper S.L., Guan J.: "Advances in Polyurethane Biomaterials", Elsevier BV, Amsterdam 2016.

[11] Woźniak P., Bil M., Ryszkowska J. et al.: Acta Biomaterialia 2010, 6 (7), 2484. http://dx.doi.org/10.1016/j.actbio.2009.10.022

[12] „Biomateriały tom 4” (Eds. Błażewicz S., Marciniak J.), Wydawnictwo EXIT, 2017.

[13] Twaiq F., Chang K.X., Ling J.Y.W.: IOP Conference Series: Materials Science and Engineering 2017, 206, 012066.

[14] Fizir M., Dramou P., Dahiru N.S. et al.: Microchimica Acta 2018, 185, 389. https://doi.org/10.1007/s00604-018-2908-1

[15] Rozhina E., Ishmuhametov I., Batasheva S. et al.: BioNanoScience 2018, 8, 310. http://dx.doi.org/10.1007/s12668-017-0453-8

[16] Matusik J.: “Natural and synthetic layered minerals in nanotechnology", Wydawnictwo AGH, Kraków, 2017.

[17] Sulong A.B., Gaaz T.S., Sahari J.: Procedia-Social and Behavioral Sciences 2015, 195, 2748. https://doi.org/10.1016/j.sbspro.2015.06.386

[18] Gaaz T.S., Sulong A.B., Ansari M.N.M. et al.: Materials Technology Advanced Performance Materials 2016, 32, 430.

https://doi.org/10.1080/10667857.2016.1265278

[19] Gaaz T.S., Luaibi H.M., Al.-Amiery A.A. et al.: Results in Physics 2018, 9, 33.

https://doi.org/10.1016/j.rinp.2018.02.008

[20] Martini J., Pollet E., Averous L. et al.: Polymer 2014, 55, 5226.

https://doi.org/10.1016/j.polymer.2014.08.049

[21] Sołtys J., Schomburg J., Sakiewicz P. et al.: „Sorbenty mineralne. Surowce, energetyka, ochrona środowiska, nowoczesne technologie", Wydaw. AGH, 2013, pp. 457-469.

[22] Wierzbicka E., Legocka I., Wardzińska-Jarmulska E. et al.: Polimery 2016, 61, 670. http://dx.doi.org/10.14314/polimery.2016.670

[23] Szczepanik B., Słomkiewicz P., Garnuszek M. et al.: Journal of Molecular Structure 2015, 1084, 16. https://doi.org/10.1016/j.molstruc.2014.12.008

[24] Bardon C., Bieber M.T, Cuiec L., et al.: Revue de l'Institut Francais du Pétrole 2006, 38, 621. https://doi.org/10.2516/ogst:1983037

[25] Derkowski A., Bristow T.F.: Clays and Clay Minerals 2012, 60, 348. http://dx.doi.org/10.1346/CCMN.2012.0600402

[26] Orsini L., Remy J.C.: Science du sol 1976, 4, 269.

[27] Środoń J.: Clay Minerals 2009, 44, 421. https://doi.org/10.1180/claymin.2009.044.4.421

[28] Kumar A.P., Depan D., Singh Tomer N. et al.: Progress in Polymer Science 2009, 34, 479. https://doi.org/10.1016/j.progpolymsci.2009.01.002

[29] https://www.campusplastics.com/campus/en/ datasheet/Elastollan\%C2\%AE+1185+A/BASF+Polyur ethanes+GmbH/59/65a16011 (available May 17, 2020).

[30] Troadec M.B., Glaise D., Lamirault G. et al.: Genomics 2006, 87, 93. https://doi.org/10.1016/j.ygeno.2005.08.016

[31] Mrowka M., Machoczek T., Jureczko P. et al.: Polish Journal of Chemical Technology 2019, 1, 1. https://dx.doi./10.2478/pjct-2019-0001

Received 10 III 2020. 